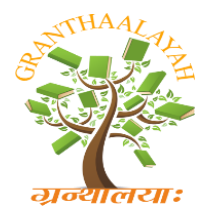

INTERNATIONAL JOURNAL OF RESEARCH GRANTHAALAYAH

A knowledge Repository

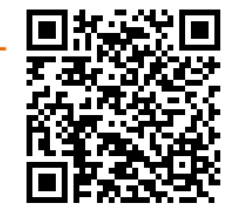

Management

\title{
AN ANALYTICAL STUDY ON THE EXPORT PERFORMANCE OF DAIRY INDUSTRY IN INDIA
}

\author{
Shiv Kumar ${ }^{* 1}$, Md. Kashif Ansari ${ }^{2}$ \\ ${ }^{* 1,2}$ Department of Commerce, Delhi School of Economics, University of Delhi, Delhi-7, INDIA
}

\begin{abstract}
With the rise of factory farming, milk is now almost an unnatural operation. The modern dairy farm can have hundreds, even thousands of cows. Today's average dairy cow produces six to seven times as much milk as she did a century ago. Currently, the United States is the largest producer of milk in the world, followed by India and China. India being one of the largest milk producer around the world, has to import a part of Milk products and its exports are negligible in the World Export Share.

This paper tries to examine the issues regarding 'Export Performance of Dairy Industry of India': Trends, Challenges and suggestions for improving the trade situation. The existing Literature has been reviewed accordingly comprising Trade Exports, Imports and the factors which are affecting the Milk Production in country. The Objectives of the study is to find out the reasons for the low per unit production, Imports and negligible exports. In Nutshell, it can be said that there are many unexplored areas in which researchers can explore the findings which can be helpful in achieving trade balance of the Indian Economy.
\end{abstract}

Keywords:

Compound Annual Growth Rate, Contract Farming, Small Scale Farmers, Quantitative Trade Restrictions.

Cite This Article: Shiv Kumar, and Md. Kashif Ansari, "AN ANALYTICAL STUDY ON THE EXPORT PERFORMANCE OF DAIRY INDUSTRY IN INDIA" International Journal of Research - Granthaalayah, Vol. 4, No. 1 (2016): 153-157.

\section{INTRODUCTION}

Indian Dairy Industry is one of the largest and fast growing industries in the country which provide ample job opportunities and contribute significantly to the economy of the country. India now has indisputably the world's biggest dairy industry- at least in terms of milk products, last year (2014-15) India produced close to 100 million, 15\% more than US and three times as China. India also produces the biggest directory or encyclopedia of any world dairy industry. The dairy sector in the India has shown remarkable development in the past decade and India has now become one of the largest producers of milk and value-added milk products in the world. Projected data suggests that India would even take over European Union by 2020.In India, Uttar 
Pradesh, Maharashtra, Himachal Pradesh, Punjab, Rajasthan, Madhya Pradesh, Tamil Nadu are the major production area of Dairy Products in India. India's Export of dairy Products was 66424.34MT to the world to the net worth of ₹ 1205.38 crores during the year 2014-15. Major Export Destination for the Dairy Products were Bangladesh, United Arab Emirates, Pakistan, Nepal and Bhutan etc.

From Independence to current scenario Indian dairy Industry has grown so much. After Independence, The government monopolized the supply of Milk Production to provide milk products to urban customers at a very low price. This has resulted in proliferation of middle-men and Production was observed to be low. Then, Government allotted high funds for the Operation Flood Programme in Fourth Five year plan. The Government restricted the outside competition in the Dairy Industry by restricting the Foreign Products like low cost Milk Powder and Import of Milk. Thus domestic industry was protected and growth in the industry was clearly visible. Soon after, the government launched the policy of Globalization and Milk production in Dairy Sector was de-licensed and exponentially growth was seen in Dairy Industry. Indian Dairy Industry has high potential of increase in volume of production. Trend in Milk Production suggests that growth opportunity exists in Dairy sector Exports.

Past Data shows that there is there is a tremendous growth in the years after 2011-12. But there is decline of exports in the 2014-15 But India's Share in global exports is still very less. There are growth opportunities and challenges in the Dairy sector which are to be studied in this Analysis.

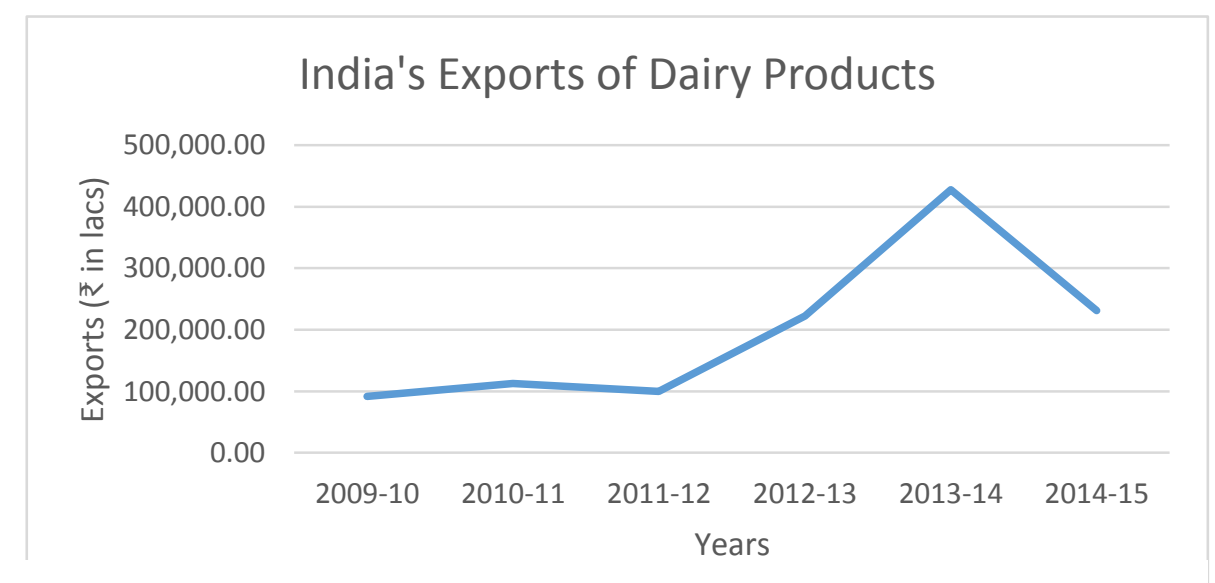

Source: Export-Import Data Bank: Directorate General of Foreign Trade

\section{OBJECTIVES}

- To study the behaviour of major importers.

- To analyse the export performance of Indian Dairy Industry.

- To study the competitive advantage of the industry if any.

- To study Global Demand and export growth opportunities.

- To assess the implications of research in further economic growth. 


\section{LITERATURE REVIEW}

The Investigator has surveyed the relevant literature on the subject. The Literature review followed theoretical introduction long and divided into two broad sections; the first section deals with issues and concerns in the export performance of Indian Dairy Industry and second section deals with the review of relevant literature. The Review ends with the research gap, which exists in the earlier research work.

The Literature Review surveyed the literature on the subject critically ending with the identification of research gap, which existed, in the earlier research work and the research question was framed. The literature survey is based on Research Papers, Thesis and Journals. The Section concludes with a summary of entire review. Topic for the Research is analytical and comparative and not much research has been done.

Manitra Rakotoarisoa and Ashok Gulati (2006) in their Research Paper 'Competitiveness and trade potential of India's dairy industry' analysed the dairy industry's growth during the period 1975-2001. Results suggested that India's Dairy Industry has become very competitive. Domestic Supplies for raw milk is relatively price inelastic. But increase in World Prices will significantly increase the Indian Exports of Milk Products. Due to heavy demand in domestic market, India's exports would remain weak unless distortion in World Dairy Market are cut, leading to high world prices and unless productivity increases and reforms are made, leading to a larger and more elastic Milk supply.

India's Dairy Sector could be benefitted if dairy Distortions in developed countries like Canada, the EU countries and the USA are removed. But India also needed some reforms to increase productivity and efficiency in Milk Productivity and Processing. Small scale farmers are also to be linked to the market through cooperative and contract farming to benefit from the increasing domestic and foreign demand. Animal Health and Hygiene factor is also an issue in this regard. Infrastructure facility also needs improvement. This suggests that the export performance for the Dairy Products should be analysed in order to assess the need of reasons for increase in export share of India in this area.

Brijesh Jha in his Thesis Entitled 'India's Dairy Sector in Emerging Trade Order' has analysed the growth of Dairy Industry in India. Exports are dominated by the US, New Zealand, EU and Australia. India also exports a good amount of milk products. It is often constrained by the arbitrary quality standards of some developed countries. In India dairy Trade has gained importance after trade liberalization of 1991.In 90s Dairy Trade has fluctuated so that it was not easy to assess any trend. The reason for the fluctuation is primly due to World Prices. In total, India is a net importer of Dairy Products in past years of 90s but it has emerged as a net exporter in current years.

In an article published in Economic and Political Weekly entitled Multilateral Trade and Dairy Commodity Markets in LDCs - Recent Evidence from Delhi, C. S. Sundaresan says that the Domestic Market for dairy commodities and the industry in developing countries are exposed to international competition from developed countries, mainly because of heavy subsidies prevailing in the farm sector for production and international trade in the developed 
countries. Therefore, Developing Countries in Asia are not in position to achieve desired competitive advantage in the International Market. Also, they fulfil the international norms in subsidies and other trade distortion measures in their domestic sectors. Domestic Market Protection prevailing in India proves this rationality for an argument against the international subsidies. Regional diplomatic organisation and governments have to come in forward in order to safeguard the trade interest of member countries.

In an article entitled 'India's Dairy Exports: Opportunities, Challenges and Strategies' by Rakesh Mohan Joshi, India is the largest milk producing country and contributes about $15 \%$ of total world milk production. But due to rapid increase in domestic demand of Milk, it became net importer in 2010-12. India's total share in global milk export is $0.68 \%$ and share in imports is $0.04 \%$. This trade pattern is directly related to milk production. There are some limitation in increasing Milk Exports from India like; in India Buffalo Milk is much more available than cow Milk whereas people in developed countries prefer cow Milk instead of Buffalo Milk. Large Scale production is not a feature of Indian dairy Industry therefore economies of scale can't be achieved. Per unit production is also very less in India. Also, Domestic demand is high in India which also leads to low surplus for exporting.

GATT has failed in creating fair international agriculture market. Some developed countries protected their high cost products by imposing quantitative restriction and levying import restrictions which enhanced their domestic production and due to high cost these can be disposed-off in International market only with the help of export subsidies. These subsidised sales depress the International market prices which directly affected the exports of developed countries. Again the same problem is found in Developing Countries, their government encourage production by subsidising it. Which causes over-production and disposed-off in International Market at low prices. This causes disruption in International Markets. There are many emerging challenges for Indian Economy which can affect Dairy Exports. As import tariffs and quota restrictions are decreasing, quality barriers may arise in high income countries as to restrict exports from countries like India. Therefore, Dairy exports should be reviewed in order to find out the causes for decrease in export share of India.

Opportunities and Challenges in Indian Dairy Industry Supply Chain: A Literature Review by Rajeev Kumar and Dr. Raj Kiran Prabhakar suggests tremendous scope of growth in Indian dairy Industry. The Indian dairy industry reported a market size of USD 48.5 billion in FY2011. With Compound Annual Growth of 16\%, it is anticipated to reach USD 118 billion in 2017. Currently, Indian dairy market is growing at the rate of 7\%. India is one of the largest milk producing country but its share in world trade is negligible. Despite increase in production, there is a demand and supply gap due change in consumption habits and rapid urbanisation. The ever-rise in demand and large demand-supply gap could lead India to be NetImporter of Dairy Products in future.

Due to the implications in Policy Formulation for increasing growth in Dairy Industry, relevant research should be done. 


\section{CONCLUSION}

In this paper, an attempt has been made to analyse the trends and challenges of Exports of Dairy Industry in India. The Literature on Exports has been analysed by segregating extant studies on different parameters with focus on Dairy Production Techniques. To conclude, it can be said that the area of Exporting Dairy Products holds promising prospects for future researchers as it has many facets which are still unexplored. Due to large production and very less exports and increasing consumption of Dairy Products, it becomes essential to understand and analyse the most recent trends of Exports and Imports as well in Dairy Sector and find out the measures to increase the exports of Dairy Products.

\section{REFERENCES}

[1] Agricultural and Processed Food Products Export development Authority, India. (n.d.). Retrieved from www.apeda.gov.in.

[2] Dairy and Product Annual, New Delhi (2014). US Dept. of Agriculture. Retrieved from.http://gain.fas.usda.gov/Recent\%20GAIN\%20Publications/Dairy\%20and\%20Produ cts\%20Annual_New\%20Delhi_India_10-15-2014.pdf

[3] Export of Indian Dairy Products in the Era of Trade Liberalization. (n.d.) Retrieved from http://www.crida.in/agrl_martng/ISAM/PDF\%20FILES/T-I/Reddy.pdf.

[4] Jha., B. India's Dairy Sector in Emerging Trade Order.

[5] Joshi., R.M. India's Dairy Exports: Opportunities, Challenges and Strategies. Retrieved from http://www.dairyknowledge.in/sites/default/files/ch6.pdf

[6] Kumar., R., Dr. Prabhakar., R.K. Opportunities And Challenges In Indian Dairy Industry Supply Chain : A Literature Review

[7] Manitra., R., Gulati., A. (2006). 'Competitiveness and trade potential of India's dairy industry'.

[8] Organisation for Economic Cooperation and Development - Food and Agricultural Organisation, Agricultural Outlook 2013-22. (n.d.)

[9] Sundaresan., C.S. Multilateral Trade and Dairy Commodity Markets in LDCs: Recent Evidence from Delhi. Economic and Political Weekly, Vol. 36, No. 34 (Aug. 25-31, 2001), pp. 3311-3315. 